\title{
The Construction of Policy: Donors, AIDS and Cultural Practices
}

The $15^{\text {th }}$ International Conference on AIDS took place in Bangkok. Delegates welcomed an increase in funding to combat the disease but disagreed how to spend the money most effectively. Politics rather than science dominated the discussions. (The Economist, 17 July 2004)

This chapter explores the dynamics of the policy development process. By focusing on narratives, I show that the policy process is not characterised by rational policymaking but by people's views and interpretations. First, I analyse the process of policy construction. Second, I look at the aid game in Malawi. Third, I look at how these narratives have been passed on through education. Fourth, I present data from interviews I conducted with UNAIDS to present stakeholders' responses to the question Does your organisation use evidence to inform policy and programmatic decisions on HIV/AIDS? In my conclusion I reflect on the policymaking process and why policy and programmes on HIV prevention in Malawi are ineffective.

\section{The Process of Policy Construction}

In the 1990s we witnessed a great rush to produce global policies on AIDS (see Chapter 4 on international frameworks on AIDS): it was acknowledged that the greatest impact of the AIDS pandemic had taken place in low and middle-income countries, particularly in sub-Saharan Africa. The international AIDS community produced policy documents

(C) The Author(s) 2019

S. Page, Development, Sexual Cultural Practices and HIV/AIDS in Africa, https://doi.org/10.1007/978-3-030-04119-9_6 
in abundance, raising and spending millions of pounds on prevention, and although the number of new infections had been falling (UNAIDS 2010) there is not much evidence that policy (Ainsworth and Teokul 2000) nor prevention programmes have been effective (Potts et al. 2008). As Chin argues, HIV prevention programmes have only received limited success (Chin 2007). I present three examples to demonstrate how policy and prevention programmes are not working. Firstly, Ainsworth and Teokul (2000) state:

[T]here are remarkably few policy success stories on a national scale. Thailand is the clearest case: after an intense national campaign to raise condom use in commercial sex, the condom use rate for brothel-based sex workers reached more than $90 \%$, STD cased declined precipitously, and HIV prevalence among army conscripts dropped by more than half. Infection rates among pregnant women have since declined, although are still high at $1-2 \%$, and these accomplishments seem mostly sustained throughout the East Asian financial crisis. In Uganda, HIV prevalence has declined among pregnant women and young people who are delaying sexual activity. However, it is difficult to attribute either of these outcomes to public policy. The decline in prevalence may be due to heightened mortality among HIV-positive individuals or the natural evolution of human behaviour faced with a generation of high mortality associated with sexual behaviour. (Ainsworth and Teokul 2000, p. 55)

Second, a mathematical modelling tool, known as the modes of transmission model, is used by decision-makers to target measures for preventing HIV infection. The model estimates the number of new HIV infections that will be acquired over the ensuing year by individuals in risk groups that have been identified in a given population using data on the size of the groups, the aggregate risk behaviour in each group, the current prevalence of HIV infection among the sexual or injecting drug partners of individuals in each group and the probability of HIV transmission associated with different risk behaviours (Case et al. 2012). There is evidence from modelling that incidence tended to peak around the mid-late 1990s (Shelton et al. 2006), before much was done regarding HIV prevention. For example, in Malawi the models show incidence peaked in 1997 at 1.91 and by 2011 it was 0.45 , but little donor money for AIDS had come into the country before 1997, and the NAC was not formed and active until well after 2000 .

Third, money has kept Persons Living With AIDs alive via AntiRetroviral Therapy, and that might have some prevention impact by 
lowering viral load, but it is not yet known how much this has contributed to reducing incidence, and in the longer run it might not matter much if inconsistent adherence produces mutations in the virus that cancel these effects.

UNAIDS, a programme established in 1996 by six UN agencies to follow on from the work of the World Health Organisation's Global Programme on AIDS in 1987, was an attempt to coordinate efforts to curb the pandemic. The UN Millennium Declaration, signed by the majority of world leaders, put HIV/AIDS at the top of the international policy agenda. At the first-ever Special Session on HIV/AIDS of the United Nations General Assembly (UNGASS) in 2001, UN Member States strengthened the response to Millennium Development Goal 6 by unanimously endorsing the Declaration of Commitment on HIV/AIDS. This Declaration included time-bound pledges to generate measurable action and concrete progress in the AIDS response. At the five-year review of the implementation of the Declaration of Commitment in 2006, UN Member States reaffirmed the pledges made at the 2001 Special Session. Also, in the Political Declaration on HIV/AIDS, they committed to taking action to move towards universal access to HIV prevention, treatment, care and support by 2010 (UNAIDS 2008).

Despite such efforts, the reaction of policymakers in the Global South has been incredibly varied. Some have placed AIDS at the top of the policy agenda and established National AIDS Commissions. However, where National AIDS Commissions have been created the problem has not been fixed (Putzel 2004). Studies refer to the success stories of Senegal and Uganda and claim that infection rates were reduced due to political leadership (Putzel 2003; Moran 2004; Putzel et al. 2006; Foley 2010). South Africa, by contrast, witnessed some of the highest prevalence rates in the world due to the reluctance of politicians to act upon the evidence and respond to the disease. The National Party had 'little incentive to mobilize public resources to counter its impact' (Fourie 2006 , p. 52), particularly as the virus appeared primarily in marginalised groups, such as sex workers and white gay men.

The biomedical evidence tells us about the causes of the disease and how to stop it from spreading. It is accepted in global health policy circles that it is sexually transmitted and that it can be prevented by abstinence, mutual fidelity in a partnership that is concordant seronegative or consistent competent condom use. Yet politicians can only take effective action if they take on board the epidemiological characteristics of the 
virus. The questions that emerge from my research are: (1) Why has the biomedical view failed to dominate the prevention discourses in Malawi? (2) Why has the international policy community strayed from this knowledge and adopted the narratives of blame constructed by the elite in Malawi?

In most countries in the Global South, AIDS is on the policy agenda. In Malawi policies and programmes on AIDS and sexual cultural practices are not informed by evidence. If this is the case in Malawi is it also true elsewhere? Stakeholders and policymakers think they have evidence, as my interviews presented above highlight. For example, data coming from misreporting, from advocacy documents such as those produced by development agencies or from focus groups and surveys that are small scale are then used to quantify large claims about the causes and reasons for Malawi's high transmission rate. There also seems to be an overemphasis on quantitative data and that numbers provide more 'evidence' than qualitative data. A senior manager working for DFID told me: 'DFID pushes numbers. Much more so than we did in the past' (P30). Another respondent working for USAID informed me that a problem was that people do not accept qualitative, ethnographic studies as evidence (P32). However, it is the qualitative analysis of local peoples' perceptions and knowledge around AIDS and attitudes towards sexual behaviour that give us a much more in-depth picture of how prevalent 'at risk' behaviour actually is and offer possible ways of challenging or breaking cycles of transmission.

Local NGOs are asked to generate numbers, which they dutifully do, but the qualitative analysis that seeks to understand why people hold the views they do is rarely done. In other words, the data on transmission are stark, we can accept it is high, but understanding why it is so is left to the Malawian elite to interpret rather than a rigorous process of systematic ethnographic qualitative research. INGOs presented with the data turn to the elites and ask them to explain it; the narratives of blame have thereby been constructed and presented as the 'why' transmission is high. My interviews and analysis show that the international community then accepts these interpretations which in turn take on a certain 'mythical truth' about transmission rates in Malawi. My data reveal that those national actors asked, for example by DFID, to come up with explanations for the high prevalence do so with vested interests-for example and as Chapters 4 and 5 have shown, they are also driven by religious beliefs and/or by financial incentives. It is hardly surprising that the 
resulting HIV prevention programmes are largely ineffective in curbing transmission-they simply do not get to the root of the problem as defined through and by the biomedical evidence.

\section{The Development Policy Process}

\section{What Is Policy?}

There are confusingly many different definitions for the word policy. The Oxford English Dictionary (2007) describes policy as 'a course of action adopted or proposed by an organisation or person'. Anderson (1984, p. 3) defines policy as a 'purposive course of action followed by an actor or set of actors'. 'Purposive' suggests that it is goal oriented which encompasses specific solutions to problems as well as frameworks for implementation. Buse et al. (2005, p. 6) describe health policy as embracing 'courses of action (and inaction) that affect the set of institutions, organisations, services and funding arrangements of the health system'. Many scholars stress that policy is inherently political (Foucault 1991), and in some countries, for example France and Spain, the word policy and politics are the same. Policy draws on concepts from several disciplines: economics, history, political science, public administration and sociology and emerged as a sub-discipline in the late 1960s, mainly in the United States.

Development policy has traditionally been seen as a state-led public policy (Hogwood and Gunn 1984; Grindle and Thomas 1991). However, scholars have recognised a shift in the policymaking process, which now involves a larger group of actors (Buse et al. 2005). It is increasingly observed that the policy process landscape is changing and that public policy is not constrained to the government. Different groups-governments, civil society organisations, coalitions, networks, NGOs, the private sector and religious groups as well as national and international media-are important players in policy development. Bilateral, multilateral agencies and NGOs have their own policies and partnerships between the public and private sector take place which also change the policy landscape. It is therefore not surprising that with so many different policies and partnerships that the policy process becomes confusing and muddled and, as a result, programmes are difficult to monitor and evaluate.

The following examples reveal how policy is made among different actors. When I asked a senior manager at DFID in Malawi 'Can 
you explain how policy is made within DFID at the country level?' she explained:

It depends on the issue. Sometimes we are leading. Sometimes we are following. DFID buys into the country led approach. It is about what is needed in the country and what the Government of Malawi wants to do on HIV. HIV is a massive problem. So here right now we are continuing with a policy that is already up and running. We continue to monitor a whole set of indicators. We have a key request to disburse $£ 8$ million pounds for the Sector Wide Approach. There are gaps regarding challenges and opportunities. Policy is ongoing - you need to check you are on track and you are not missing a trick. (P30)

This passage clearly highlights the extent to which DFID follows and adopts both the policies and explanations behind them already formulated at the national level. She went on to say: 'One thing DFID has done a lot of is trying to solve problems' (P30). DFID sees itself as a trouble shooter swooping into sort out implementation challenges, it does not however seem to take the lead in the design of policy or even the collection of data by which policy may be evidenced.

When I asked the Country Director of World Vision how do they develop policy he said: "We try to look at government country level policies-like HIV/AIDS. We interpret policies and work "hand in hand". We also work with different donors. We have received money from DFID for work in the past' (P28).

So again, World Vision is admitting here to not taking a lead role in the formulation of policy but rather works with national actors on the implantation of pre-agreed priorities accepting the evidence and narratives put forward by national stakeholders justifying a particular set of actions. Similarly one respondent at USAID told me 'USAID's work depends on the policies of the government' (P31). Once again we see the role of the bilateral and multilateral aid community to be one of supporting and funding implementation not questioning or challenging the wisdom of the national strategies themselves. A policy document entitled 'Malawi -German Health Programme, Malawi-German cooperation in the health sector', revealed:

The Malawian and the German governments cooperate closely in the sectors basic education, democratic decentralisation and health. MalawiGerman cooperation with the health sector has a long history going back to the 1980s. Its ultimate goal is to improve the health status of the 
population. The German government supports the SWAp as a means of efficiently delivering the range of health services specified under the EHP. (n.d., p. 5)

In my interviews with staff at UNAIDS it was clear that they were unhappy with the operational structures of the Government of Malawi and specifically the way that the national AIDS strategy was put together and presented. Staff told me they felt it had been compiled in a rush with no adherence to participatory methodology that stresses the need for local views and experiences to be gathered systematically feeding into the policymaking process. In fact, on numerous occasions, I heard staff describe the process as 'quick and dirty'. They felt that the involvement of the private sector in the policy process might have resulted in a much more robust and transparent process of programme design. Instead it was unclear how the resulting programmes were put together, and no clear evidence for the narratives around high transmission available. What is interesting and also troubling is why did UNAIDS not question the narratives emerging from the process if they were unhappy with it and if participation was not happening. The UNAIDS Programme Officer said:

The private sector has no participation in this process. It wasn't like the forum of active participation. Organisations such as MANET+ and NAPHAM had no consistent opinion and there was no advocacy. The forum in which it was done did not influence active participation. It wasn't very well organised. (P59)

This lack of public critical questioning of the policymaking process is apparent according to the INGOs and donors I interviewed and reveals clear apathy on their part. A reluctance to challenge the government, yet clearly privately acknowledged that the policies and frameworks were not robust. Part of this apathy may be due to contradictory views on the role of these agencies, for example according to UNAIDS its remit is as a facilitating agency however when I interviewed a UNAIDS staff member I was told 'UNAIDS prevention strategy has tried to influence the national prevention strategy' (UNAIDS consultancy 16 April 2009). This point of view completely contrasts to the view of the Programme Officer, UNAIDS who I also interviewed who said several times that UNAIDS role was to facilitate, not to influence (P25). This confusion provides an explanation as to why national policy processes remain unchallenged and why certain inaccurate narratives then become taken up without the supporting evidence. 
Further explanation emerges through the fact that donors are not always in agreement with each other. So there is no united front between the donor community, this in itself is problematic as concerns are not shared. For example, A DFID staff member informed me that:

There are issues we have with the Global Fund. Donors are disagreeing over basket funding. We have to negotiate with the Ministry of Finance. Different donors have more or less strict rules and then there are the Global Fund's rules. DFID believes in basket funds and SWAps. (P30)

The next section looks at the theoretical models of policymaking.

\section{The Schools of Policymaking}

The concept of policy proposes a puzzling mix of frameworks and theories ranging from extremely prescriptive to descriptive (Heclo 1972). Although there are many theories on how policy is made, understanding how the process works has been principally constrained with two opposing approaches to development policy. These can be summarised as follows. On the one hand there is a rational approach to policy, which was pioneered by Laswell in the 1950s (Laswell 1956). This public policy model, also known as the linear or knowledge-driven model or stages heuristic, assumes that policy is a one-way process and that policymakers approach issues in a linear fashion while identifying different stages of the process. Significant features of the rational model are a focus on agenda setting, policy formulation, decision-making, implementation and evaluation (Young and Quinn 2002). Foltz describes the rational approach as decision-making that can be carried out in an 'orderly fashion, starting with assessment of the problem, collection of data, synthesis, weighing of the alternatives, selecting objectives and actions and a system to evaluate performance and outcome' (Foltz 1996, p. 210). According to ODI, the rational model assumes a clear separation between fact (based on evidence, science and objective knowledge) and value (seen as a separate issue, dealt with in the political process). The rational model is also seen as prescriptive and presents an 'ideal model' of how policymaking should happen, providing a way of ameliorating the effectiveness of policymaking through the identification of values and goals before making policy choices and opting for the best policy options based on information regarding the costs and consequence of each (Simon 1957). This model 
was also seen as the solution to fixing political problems faced by public administrators. Gordon et al. propose that the linear model is 'a normative model and a "dignified" myth which often shared by policy-makers themselves' (1993, p. 8, cited by, Shore and Wright 1997). As Mosse points out:

Now extensive literature argues that development's rational models achieve cognitive control and social regulation; they enhance state capacity and expand bureaucratic control (particularly over marginal areas and people); they reproduce hierarchies of knowledge (scientific over indigenous) and society (developer over 'to be developed') and they fragment, subjugate, silence or erase the local, all the while 'whisk[ing] these political effects out of sight' through technical discourses that naturalize poverty and objectify the poor and depoliticize development. (Mosse 2004, p. 4)

Nonetheless such approaches continue to be perpetuated as part of the policy development and planning techniques of international development agencies which have encouraged non governmental agencies and governments to use them. Yet this type of framework fails to recognise the gap between theory and practice and many scholars have attacked the rational approach. Sabatier (2007) criticises this model as it presumes a linearity to the public policy process that does not exist in reality, it posits neat demarcations between stages that are obfuscated in practice, and suggests no propositions on causality. In a report for ODI, the UK's independent think tank on international development and humanitarian issues, Young and Mendizabal (2009) concludes that 'more evidence-based development policy may not be possible with traditional linear tools and approaches' (p. 3). In other words, the linear nature of such models is blocking the path for evidence-based policy. Linear tools used in development planning include the logical framework which is a management tool mainly used in the design, M\&E of international development projects. Authors sum up problems with the Logframe Approach (LFA):

Unfortunately (for the logical framework approach at least) we are not working with such a self-contained system and there are so many factors involved which lie beyond the scope of the planned initiative that will change the way things work. Although the LFA makes some attempt to capture these through the consideration of the risks and assumptions, these are limited by the imagination and experience of those involved. As a result 
the LFA tends to be one-dimensional and fails to reflect the messy realities facing development actors. (Bakewell and Garbutt 2005, p. 12).

Some scholars talk about the 'non-linearity' of policy where policy is often contested, reshaped or initiated from different points between macro and micro levels (Lipsky 1980; Lindblom 1980; Shore and Wright 1997). On the other hand there is an incrementalist view which, as a criticism to the rational model of the policy process, the incrementalist model was put forward. The principle advocate of this model is Lindblom (1959, cited by Walt and Gilson 1994) who is concerned with the process of bargaining between different interest groups in the course of policymaking. This model also assumes incremental changes are made over time in order to decrease uncertainty, conflict and complexity in processes of policy change and has descriptive overtones. It is incremental in that the process does not commence with objectives but with what exists and how one can proceed from this point.

However, literature on policy processes is now shifting away from the linear and incremental model and demonstrates such frameworks to be an inadequate reflection of policymaking in practice (Clay and Shaffer 1994; Hajer 1995; Keeley and Scoones 1999). There is a third alternative to these models, and the view that I follow, which looks at the policy process consisting of power dynamics, relationships and vested interests of actors who are driven and constrained by the contexts within which they operate. My view gained from my professional experience working as a Consultant to governments and organisations on strategic planning and policy development resonates with recent literature, which emphasises the complex and messy processes by which policies are understood, formulated and implemented and the range of competing actors' interests involved (Keeley and Scoones 2003). Clay and Shaffer's 1984 book, Room for Manoeuvre, describe 'the whole life of policy as a chaos of purposes and accidents. It is not at all a matter of the rational implementation of the so-called decisions through selected strategies' (cited by, Keeley and Scoones 1999, p. 33). Walt and Gilson (1994) observe that rarely scholars look at the process of policymaking, the actors involved and the context in which those actors operate, but instead focus on content. Ramalingam et al. (2008) describe the process as nonlinear and complex with a multitude of factors involved. Keeley and Scoones $(2000$, p. 4) argue that this complexity 'may allow spaces for the assertion of alternative storylines and practices, which, in turn, can gradually result in substantial challenges or shifts in the knowledge and practices 
associated with previously dominant discourses'. This can be seen in the Malawian context where the process is complex due to the amount of actors involved in policymaking.

Keeley and Scoones $(1999,2003)$ suggest that policymaking requires three broad approaches. One, policy emphasises political economy and interaction of state and civil society and different interest groups. Two, it examines histories and practices linked to shifting discourse and three, it gives primacy to roles and agency of individual actors. There is an integration of different but overlapping perspectives, rooted in different schools of thought and disciplines, which explore how actors make and shape policy narratives and interests while at the same time being constrained. McGee (2004) talks of the 'unpacking' of policy by looking at three different concepts: actors, knowledge and spaces. IDS (2006) adopt a similar conceptual framework to analyse the policy process but refer to three interconnected themes, namely discourse/narratives; actors/networks and politics/interests. It is important to note that the policy process does not take place in a void. Rather it takes place within a context in which history, culture, political economy, politics and power relations shape aspects of the context, the policy spaces and the way actors and knowledge interrelate to them (McGee 2004, p. 23).

The role of NGOs in the policy process compared to district governments is often confusing as I discovered (Box 6.1). Save the Children was once the umbrella organisation in Balaka and was responsible for distributing funds. Then the Government changed the system and put the district government in charge of funding CBOs. Officials were sent from NAC headquarters in Lilongwe to provide training to CBOs on proposal writing to secure funds. What I then found was that the proposals submitted by the CBOs and FBOS after NAC officers had provided training on proposal writing the majority of $\mathrm{CBOs}$ were asking for funds to work on eradicating cultural practices. This has to be questioned as to why most CBOs that had different organisational objectives would be requesting funds for eradicating sexual cultural practices. For example, I obtained the proposals from Balaka District Council and it was clear from my analysis of them that the current trend at the time focused on the eradication of HCPs and CBOs knew that if they asked for money to work on cultural practices and behaviour change they would be more likely to secure it, whether or not they then used these funds on projects focused on eradicating HCPs is not clear, it is possible they diverted funding into their own commitments, through which perhaps a degree of meaningful impact was in fact achieved. 


\section{Box 6.1 P15 Interview with a District Youth Officer}

S: Okay, let's continue with your work, how do you get funding from the Ministry of Health $(\mathrm{MoH})$, do you get it directly?

R: We get funding from various NGOs, we have the Malawi Bridge project in Lilongwe, we have worked with them they have assisted us in many areas, we are also working with other NGOs like Concern Universal, Self Help Africa, formerly known as Self Help Development International, MACOHA, and there are a lot of NGOs, based in Balaka, they are working in Balaka and Ntcheu. The coordinator is based in Ntcheu; we combine the districts Balaka and Ntcheu. Save the Children, they phased out but we have worked with them, PSI, Blantyre Synod, Sue Lyder foundation, YONECO, Maphunziro foundation.

$S$ : So they give you funding?

$\mathrm{R}$ : They don't directly give us funding but they conduct some activities for the youth so we take advantage of them because as government we have the programme and these people know what the government want to do with the youth. They realize that the government itself cannot manage to do all these activities; it is also depending on the NGOs.

S: How do they know what the government wants to do?

$\mathrm{R}$ : We have stakeholders meeting with them at least once or twice a year

S: With all the NGOs?

R: With all of them and during such meeting we disseminate what the youth policy is all about and its during this stakeholders meeting it's when the NGOs know what the youth policy is all about, say about the youth. So what they are doing it has to be in line with the youth policy.

S: So how does it work?

$\mathrm{R}$ : If they are not doing what is in line with the youth policy, we have to tell them that no, this is not what the youth policy says about the youth, this is what you are supposed to be doing.

S: So do they do their activities independently?

$\mathrm{R}$ : Of course they can do things independently but they have to follow what is in the youth policy

S: So does the youth policy mention about cultural practices?

$\mathrm{R}$ : Yes, it mentions about the cultural practices, I had a copy but somebody took it last week.

S: And the other NGOs, how do they know about trying to change cultural practices? 
R: Let's go back to the youth... I mentioned about the cultural practices that enhance the spread of HIV/AIDS among the youth, there is a mention of that.

S: Okay, how do you work with the NGOs and how do you make sure that what the NGOs are doing is in line with the national policy?

$\mathrm{R}$ : When they are implementing their activities, they inform us that this is what we want to do with the youth and we go and see their project and we sometimes advise them on how they can go about it, sometimes they invite us, say, come and see what we are doing, or before they start the programme, they invite us to see what they are doing, but there are some who are implementing youth activities without informing our office, that is an offence, if we discover them, it's an offence.

S: What do you do?

$\mathrm{R}$ : We sue them and we tell them to come and brief us on what they are doing, if they continue doing that then we sometimes, we have what we call the district executive committee. This is the committee for all heads of government and NGOs, we have that in Zomba. In this committee all the activities that are happening in the district are briefed there so if an NGO is found doing what is not in line with government policy then it's taken to task. But people are careful; they know that if we do what is not in line with what the government wants to be done. So they are much more careful about that.

I spoke to a director of an NGO in Zomba who said his organisation focused on education but he said when speaking to senior managers in charge of NGOs if staff were not personally interested in education then they would not fund projects on this topic. This is an example not just of the institutions objectives but the staff that work for the institutions. If they have personal interests in a specific issue they will not fund projects that want to address other issues even though this issue says education is important and needed in that area. This example demonstrates that even if an organisation has a strategy to implement staff working for the organisation have their own interests and can decide what will be funded. What then is the point of an organisation's strategic objectives if personal interests can get in the way?

CBOs in Malawi are often run by individuals who are motivated by a single set of community rooted issues, they will manipulate their own agenda in order to secure funds but ultimately are unwilling to side-track from their priority. Much money intended for HIV/AIDS was channelled through CBOs who were contracted to use it to eradicate HCPs, 
the lack of transparency in the process makes it difficult to know if this happened. For example, when I analysed 43 funding proposals submitted by CBOs to Balaka District Council for projects on harmful cultural practices and HIV/AIDS I found that although the project proposal stipulated they would be working on HIV/AIDS when I looked at the budget I discovered that the activities they wanted to fund were related to income generation which suggest these funds were being re-diverted for other projects which the CBO heads felt were of greater priority. These projects not only did not focus on HCP eradication but did not focus on HIV/AIDS either. The reality of this funding chain and the competing interests and priorities of each link is another key factor why donor money failed to have any dramatic impact in reversing transmission rates in Malawi.

The relationship between CBOs and INGOs in Malawi is fraught with tensions. INGOs are essentially donors who wield great power in determining how and which CBOs receives funding. As Lewis and Kanji pointedly describe:

For post-development critics such as Temple (1997), NGOs are viewed negatively as a continuation of colonial missionary traditions and as the handmaidens of the capitalist destruction of non-Western societies. Within this view, NGOs are modernizers and destroyers of local economies and communities which were once based on age-old systems of reciprocity, into which NGOs introduce undesirable Western values. (2009, p. 44)

Locally based CBOs in Malawi have found a way around the power hierarchy of the aid industry, they play the game to an extent, securing funding and then continue as they please, whether or not their efforts bring about positive development outcomes has not been closely explored as demonstrated above by my analysis of funding proposals submitted to Balaka District Council by CBOs.

$\mathrm{CBO}$ employees know how to play the donor game. But the 'big' donors who sit in their offices in the capital rarely meet the CBOs, at least not in the field, therefore have no idea what is actually needed on the ground in the villages. When I interviewed the health specialist at DFID he had been in situ for four months and he could not talk about cultural practices even though DFID had funded a project on cultural practices and were funding national NGOs and the NAC who were distributing funds to $\mathrm{CBO}$ s to work on 'sensitsing religious and traditional 
leaders' about the eradication of cultural practices which were, according to the narrative, spreading the HIV virus. Although he could not talk about the things that were being funded he volunteered to talk about 'policy'. He said:

NGOs, $\mathrm{CBOS}$ and $\mathrm{MOH}$ and $\mathrm{NAC}$ have had a role in the grant making process which is a national agreement. We support other organisations and international NGOs; for example, the Malawi Economic Justice Network. We have the right focus to ensure vulnerable groups are properly taken into account. (P4)

He then said he can get very absorbed in the process. He also said that DFID ensures that they (DFID) are aware of impact. Although DFID may be aware of impact through reporting procedures I discovered that there seems to be a disconnect between the donors and the CBOs that actually carry out the work, which seems to largely work to the advantage of local organisations who can carry on without fear of scrutiny with the agenda they themselves have set.

INGOs working in line with the government's national strategy put together training and capacity building workshops in order to help CBOs deliver and achieve on the goals of HIV/AIDS eradication (Webb 2004). As an academic pointed out who worked at the College of Medicine:

Where is the evidence? When policy was developed people did not know how HIV was spread. The perception was that if you had sex with someone who is HIV positive then you would be infected. However 20 years later epidemiologists have discovered that there is 1 in 1,000 chance of contracting HIV. (P50)

This reaffirms my point that evidence is not being used to implement policies and programmes on HIV/AIDS prevention in Malawi. Projects are funded because certain topics become the trend in the development field and the latest topic that donors want to prioritise. Yet if donors choose to increase funding for a particular issue they must decrease funding for other issues unless they can obtain additional resources (Feeny and McGillivray 2004). This can be seen in the case of HIV/AIDS funding. Shiffman (2008) found that donor prioritisation of HIV/AIDS treatment and prevention in developing countries displaced aid for other health issues. UNAIDS reported that: 
It is an unfortunate reality that budgeting procedures too often may mean that new funds for HIV/AIDS can draw resources away from other activities, either at country level, or at donor level. Therefore, all parties need to commit themselves to the principle that additional funding for HIV/AIDS is to be used for additional spending, otherwise displacement is inevitable to the detriment of overall development. (UNAIDS 2004, p. 145)

A study carried out in Malawi which looked at local people's needs revealed that villagers' main concern was not HIV/AIDS but water. Here we see a discrepancy between international policy and the reality on the ground, and how donors are not in tune with what is really needed (Dionne 2011). Ironically, and from my observations and conversations with CBOs in Malawi, it is likely that HIV/AIDS money, at least some of it, is being used to meet these more immediately perceived needs.

What I have demonstrated so far in this chapter is that policy is confusing. Who is implementing what and from what direction? (See my analytical framework.) As I have evidenced in the light of my conversations I have presented in this chapter it is difficult to identify who is making the policy decisions in the development arena because there are so many actors involved in the process. The next section looks at actors' roles as actors are key to the policymaking process.

\section{Actors}

Some authors use the term actors to refer to people, others include collectivities such as organisations or government. The term includes politicians, central government officials, local government officers, civil society organisations, NGOs and technical experts. Increasingly, new actors enter the policy process, perhaps by invitation to demonstrate stakeholder participation by those who are holding power, or for their own vested interests. Indeed, actors have vested interests; they are rooted in political and institutional cultures and they make use of agency. As demonstrated in Chapter 3 actors are constantly entering or leaving the development arena and they may have a diversity of vested interests to pursue their own agendas, as well as representing an organisation; a pertinent point which is rarely documented by the international donor community (Kaler and Watkins 2001; Luke and Watkins 2002; Dorman 2005; Marsland 2006). 
Actors have the potential to wield enormous power over policies and programmes as they produce their own interpretations of knowledge and thereby construct and influence policy. This can happen at the local, national or international level. The power of actors (agents) is often woven with the structures (organisations) to which they belong. One person told me that if initiation ceremonies were eradicated then key actors involved in the process would lose their jobs such as the initiation counsellor and the hyena. For the actors involved it is an economic activity; the initiation counsellors can earn between 3000 and 5000 kwacha (6-10 pounds) per initiation. Another person said: 'If the cultural practices were removed there would be no research to conduct and then the researchers would lose their jobs' (P44).

Actors are those who have some role in the policy process. As Brock et al. (2001, p. 3) highlight: 'an approach to policy processes that puts actors into the picture has much to offer in making sense of poverty policy processes'.

The policy process involves a complex web of interactions between a range of actors who are strategically positioned in the AIDS arena. The rise and fall of different policy emphases depend upon the ability to underpin narratives to galvanise ideas and people around positions. Policy-built on successful (or otherwise) enrolment of actors-and the creation of networks that are able to make use of policy space emerging from contexts, circumstances and timing. Latour argues that development policy ideas are important less for what they say than for who they bring together; what alliances, coalitions and consensuses they allow, both within and between organisations (Latour 1996, pp. 42-43).

\section{What Is KNOWLEDGE?}

There are different ways of understanding knowledge and therefore different types of knowledge. According to Keeley and Scoones: 'knowledge is produced discursively: it reflects and shapes particular institutional and political practices and ways of describing the world' (Keeley and Scoones 2000, p. 3). When trying to gain knowledge the social sciences tend to oscillate between two opposing concepts: positivism and constructivism. These concepts are linked to assumptions about ontology, epistemology and the philosophy of science. In this positivist versus constructivist war one of the disputes is whether human behaviour 
is 'caused' by factors external to the individual or whether a person is a participating and, in principle, freely deciding member of a culture and society (Whimster 2007). Whereas positivists can be seen as 'explainers' of reality by emphasising empiricist observation based on rational decisions, constructivists are more concerned with meaning and 'verstehen' (understanding). These 'paired oppositions' as Bourdieu (1988, p. 778) explains, 'construct reality...they construct the instruments of construction of reality: theories, conceptual schemes, questionnaires, data sets, statistical techniques, and so on'.

The social construction of policy is made up of narratives and discourses and is irrrational. Roe uses the term 'development narratives' and holds the view that narratives are stories or arguments which have a beginning, a middle and an end and revolve around a sequence of events or positions in which something happens or from which something follows' (Roe 2005, p. 314). Keeley and Scoones (2000) uphold that narratives are shaped by the policy process and also shape the way those involved in the policy process act. ODI indicate that narratives define a problem, explain how it comes about and show what needs to be done. Further validity is often gained despite the fact complex issues and processes are frequently simplified.

Discourses, however, according to Hajer, are defined as 'a specific ensemble of ideas, concepts and categorisations which are produced, reproduced and transformed in a particular set of practices and through which meaning is given to physical and social realities' (Hajer 1995, p. 44). For Roe (1991) discourses separate the way problems are thought about, connecting different issues often in highly programmatic, narrative, cause and effect form. These discourses and the institutional practices which they depend on are frequently so embedded that people are unaware of them and they form world views (Keeley and Scoones 2000). As Gasper and Apthorpe (1996) indicate, 'discourse' is understood and used in a range of different ways in the policy process literature.

Foucault (1979), who argues for the strategic reversibility of discourse, suggests:

There is not, on the one side, a discourse of power and opposite it, another discourse that runs counter to it. Discourses are tactical elements or blocks operating in the field of force relations; there can exist different and even contradictory discourses within the same strategy; they can, on 
the contrary, circulate without changing their form from one strategy to another, opposing strategy. (1979, pp. 101-102)

This is an important point as it relates to my research in that discourses on HIV/AIDS and cultural practices are being used to accuse those living in rural areas as being backwards and spreading the disease and that these practices need to be eradicated thereby creating employment opportunities for themselves.

\section{NeTWORKS}

The AIDS prevention community in Malawi is a network of professionals. Such networks are able to create knowledge and formulate policies. AIDS prevention network I focused on comprised NGOs, INGOs, local and national government, universities and bi and multilateral donors. There have been many different definitions to describe these networks. Castell (1996) describes them as a network society. Haas' (1992) notion of the 'epistemic community' is particularly useful for conceptualising the HIV/AIDS prevention community in Malawi; Haas describes an epistemic community as 'a network of professionals with recognised expertise and competence in a particular domain or issue-area' (Haas 1992 , p. 3). He posits that epistemic communities are groups of professionals, often from a variety of different disciplines, which produce policy-relevant knowledge about complex technical issues (Haas 1992, p. 16). Such communities embody a belief system around an issue which contain four knowledge elements: (1) a shared set of normative and principled beliefs, which provide a value-based rationale for the social action of community members; (2) shared causal beliefs which are derived from their analysis of practices leading or contributing to a central set of problems in their domain and which then serve as the basis for elucidating the multiple linkages between possible policy actions and desired outcomes; (3) shared notions of validity - that is, intersubjective, internally defined criteria for weighing and validating knowledge in the domain of their expertise; and (4) a common policy enterprise - that is, a set of common practices associated with a set of problems to which their professional competence is directed, presumably out of the conviction that human welfare will be enhanced as a consequence (Haas 1992, p. 3).

It is important to understand which actors set the debates and influence policy. A senior DFID staff member informed me: 'I have two health 
advisers. You met with John and are trying to hook up with Sandra. They are part of a network of professionals' (P30) and evaluators of the curriculum books included staff from USAID, UNFPA and the Ministry of Education. Staff from the UN agencies were described as 'expert judges'. These examples illustrate how those working for bi and multilateral donors are given elevated titles such as 'experts' and 'professionals' thus demonstrating their apparent expertise among the donor community. Yet their expert knowledge does not extend to understanding the local contexts which the policy endorsed intends to change. In other words, they have not spent any time gathering local contextual knowledge of AIDS.

Knowledge is constructed in policy and human beings are not blank sheets, hence knowledge is filtered through preconceived ideas and values. Thus it is not an accumulation of facts but involves ways of construing the world. Scientific evidence can be sought to justify a particular policy position however actors are able to cherry-pick points to justify their arguments. As a result policy processes include some perspectives and exclude others, often of the poor and marginalised. Policymakers can also frame scientific enquiry as I have demonstrated in this thesis. Science has been framed in the context of sexual cultural practices spreading HIV/AIDS. A combination of science and policy then plays down scientific uncertainties. Knowledge has been used in international development policy however it is important to ask how has the knowledge been gathered? Often in development, knowledge has been gathered by top-down methods and controlled by national or international elites. Local events are then being reinterpreted or reconstructed within international frameworks. Narratives about HIV policy become normalised. Discourses about harmful cultural practices in Malawi circulate so that people assume the practice is contributing to the spread of HIV but to what extent no one actually knows. One example illustrates my argument. I interviewed a Programme Officer working for UNAIDS and she said:

We've talked about the cultural practices, we have people talking about it but we don't really have evidence about what is happening in each district, but we've been told and informed by the communities, the leaders within the communities, that yes it is happening. You know, the government people, the NGOs that are working there, they are saying 'yes they are happening'. But we really want to have substantial information for us to be able to say 'yes it's an issue and we need to do something about it. (P25) 
This is an example of how evidence is not being used to support policy decisions. Keeley and Scoones (2000) point out that analysis of the policy process requires an examination of how discourses are created and supported through institutions of science, government and administration and to find out where they are contested, where they are open to incremental change and where alternative discourses are emerging and finding expression in the policy process. The concept of 'space' is used in literature on policy change (Brock and McGee 2002) and citizen participation (Jones and Gaventa 2002). Conceptualising policy arenas as 'spaces' where different discourses and actors interact builds on the influential work of Grindle and Thomas (1991). They describe policy spaces as interventions or events which create new opportunities and reconfigure relationships between actors or bring in new ones. This can be seen in the case of Malawi where stakeholders come and go: new ones enter the HIV/AIDS prevention arena where others leave and move on to different jobs in the development field. Hajer talks about 'new spaces of politics' where there are 'concrete challenges to the practices of policymaking and politics coming from below' (Hajer et al. 2003, p. 8). In their view, policy has become more deliberative: less top-down, involving networks and more interpretative, taking on board people's narratives, their understandings, values and beliefs revealed through language and behaviour. This is the view that I also hold which is policy is made on the basis of people's beliefs and not on scientific evidence. Spaces can be categorised in a number of ways. Jones identifies two dimensions: the level and the place and the forms of power maintained within them (Jones et al. 2009). Gaventa (2006) argues that the ways in which spaces are created also play a pivotal role: spaces can be closed, made by a set of actors behind closed doors; invited, where efforts are made to widen participation with citizens groups invited to participate; or, claimed, where less powerful actors create spaces or claim them against the power holder, often emerging out of common concerns or identifications.

Drawing on the conceptual work by Cornwall (2002) and Jones \& Gaventa (2002), McGee identifies five dimensions that make up a policy space: history, access, mechanics, dynamics and learning dimensions. She argues that these are pivotal factors for consideration by policy actors considering engagement or analysts trying to comprehend what drives certain episodes or outcomes of policy processes (McGee 2004, p. 18). Another typology categorises spaces according to their functions in the policy process: conceptual spaces (where new ideas are introduced), 
bureaucratic spaces (formal policymaking led by civil servants), invited spaces (where new ideas are introduced), bureaucratic spaces (formal policymaking led by civil servants), invited spaces (such as consultations), popular spaces (such as protests and social movements), practical spaces (providing opportunities for 'witnessing' by policymakers) and political/ electoral spaces (elections) (KNOTS 2006, cited by, Jones et al. 2009). These frameworks on policy spaces have helped my argument as what can be seen in the case of Malawi is certain stakeholders are invited to certain spaces (e.g., meetings) but not others (see UNAIDS example provided earlier regarding participation of the private sector) to develop policy.

One study by Wachira and Ruger (2011) presents findings on the impact of the PRSP process on Malawi's National HIV/AIDS Strategic Framework (NSF). In 2007, a survey was carried out which sought respondents' retrospective perceptions of NSF resource levels, participation, inclusion and governance before, during and after Malawi's PRSP process (2000-2004). Malawian government ministries, United Nations agencies, members of the Country Coordination Mechanism, NAC and NAC grantees were interviewed ( $n=125,90 \%$ response rate). The authors of the article also assessed the principle health sector and economic indicators and budget allocations for HIV/AIDS. Results of the survey suggested that the PRSP process supported accountability for NSF resources but that the process may have marginalised key stakeholders, potentially undercutting the implementation of HIV/AIDS Action Plans. In section “The Development Policy Process" I will now present the case of Malawi using the analytical framework in order to analyse the policy process.

\section{The Aid Game}

Donors' choice of a particular form of aid (relief, bilateral or multilateral development, policy-based or project-based assistance) reflects their global policy objectives and their analysis of how aid contributes to the development process. As development theories change and circumstances in affected countries alter, so donors have increased or decreased the proportion of their aid channelled through the state in recipient countries - the greater the international legitimacy of a recipient country's government, the more bilateral and developmental the channels of assistance are likely to be (Crewe and Young 2002). Donors' choice 
of aid instrument is also affected by the degree to which they wish to engage with the recipient state (Macrae 2001).

Donors are increasingly moving away from providing financial support to UN agencies in favour of NGOs working through field offices in country. For example, DFID provides funding to more than $100 \mathrm{UK}$ civil society organisations as well as organisations in developing countries. The 'aid chain' (Bebbington 2005) can then be very long which makes it more difficult to monitor and evaluate the impact of the funded programmes. It also makes it harder to uncover how policy and funding decisions were/are made. This can be seen in the case of Malawi. Three examples of the aid chain are: (1) DFID in Malawi funds the NAC, the NAC distributes funds to the district governments and the district governments distribute funds to community-based organisations. (2) DFID UK distributes the money to an NGO in London, the NGO in London distributes the funds to a national HIV/AIDS NGO in Malawi, the National HIV/AIDS NGO distributes it to hundreds of CBOS in the country. These examples support my argument that donors are supporting projects at many different levels of the aid chain. Although DFID, for example, may know what it is funding through the process of reporting I did not see any evidence that a National HIV/AIDS NGO reports to DFID on every single project a $\mathrm{CBO}$ is implementing but instead provides a summary of activities the NGO has funded. These CBOs are in the villages and are tiny. For example, I interviewed a Programme Officer working for UNAIDS she gave an example of how UNAIDS gives funds directly to nationally present NGOs to complement the interventions that UNAIDS is implementing. She said:

We are giving money to four NGOs in 4 districts (Chitipa, Nsanje, Ntcheu and Mangochi) to help build their capacity and implement some of their activities in relation to harmful cultural practices and HIV/AIDS. We did an expression of interest, some NGOs applied; we wanted to see if indeed if in those districts they are indeed implementing activities on HIV/AIDS and cultural practices. So, those ones have been selected but they have not been informed yet; I, myself, don't even know who they are. But we are giving them funds from this year. We have proposed that, with the Flemish, that we need the mapping of the whole country district by district, of what are the cultural practices in those areas. This is the only intervention, because what we are trying to look at with them is that this (mapping) should precede the intervention to address cultural practices. (P25) 
This example demonstrates how decisions are being made to influence policy; that four districts were randomly selected to see if cultural practices take place. This example supports my argument concerning how cultural practices are being blamed for the spread of HIV. It also highlights that in this instance the link between HIV/Aids and Harmful Cultural Practices has been accepted, the donor is requesting data on the prevalence and nature of HCP but is clearly not questioning the link. I believe that this multichain reality adds to the distortion and enables particular narratives to emerge unchallenged and unevidenced. The interview above certainly reveals that this narrative has been accepted by donors. The examples that follow also demonstrate that donors have funded work on sexual cultural practices because they believe them to be a significant factor in spreading HIV/AIDS. Several studies, reports and educational materials have been funded by international donors to identify sexual practices and their link to HIV/AIDS rather than how they supported structural gender inequalities and violence. The following section will present these examples.

One study entitled A Literature Review to support the Situational Analysis for the National Behaviour Change Interventions Strategy on HIV/AIDS and Sexual and Reproductive Health Coombes (2001) was conducted by the Liverpool Associates in Tropical Health Ltd with funding from the DFID in the UK. The study's findings, which are relevant to this research, came under the topic 'ceremonies and rituals'. It was stated that cultural practices continue to play an integral part in HIV and STI transmission (p. 93). However, the study did not name specific cultural practices neither did it refer to epidemiological data regarding HIV transmission. So once again we see a link between HIV/AIDS and HCP accepted without clear evidence beyond a narrative provided by the Malawian elite. A second study also funded by DFID in entitled A Review of Cultural Beliefs and Practices Influencing Sexual and Reproductive Health and Health Seeking Behaviour, in Malawi (Matinga and McConville 2003) makes a similar automatic link between HIV/ AIDS and HCPs. The following extract is taken from the introduction:

The aim of this brief review was to provide a summary of cultural beliefs and practices in Malawi that may serve as risk factors to sexual and reproductive health $(\mathrm{SRH})$. It is simply the first step in a process intended to consider deep-rooted cultural issues in the planning and programming of multi-sectoral activities which are focused on mainstreaming HIV/AIDS 
and improving SRH. The need for this first step arose because of the lack of accessible data. The DFID supported MoHP Safe Motherhood Programme (SMP) in the southern region is acknowledged for prompting this review by highlighting the links between beliefs, practices and SRH through a needs-based planning process. The audience for this first step is intended to be those involved in developing the Government of Malawi Sexual and Reproductive Health Programme (SRHP), HIV/AIDS organisations, and those in other sectors working towards a cross-sectoral approach. (Matinga and McConville 2003, p. 1)

This is an example of how DFID as a donor has invested money specifically to look at cultural practices because they believe them to be linked to HIV/AIDS. This report also mentions the fisi practice of particular interest to me:

'Hyena' (fisi) During the ceremony a man (often an older man) undertakes sexual acts with all the girls). His identity is a secret, but he is known as the 'hyena' (i.e. the hyena that comes out at night. SMP research in Mangochi District also notes that the fisi may insert a piece of wood into the girl, mimicking the sexual act, a point reiterated by Chirwa (CSR) who believes that much of the sexual activity is symbolic only. (Matinga and McConville (2003, p. 28)

These examples also demonstrate how DFID is funding work on sexual cultural practices despite the fact sexual cultural practices are not mentioned in DFID Malawi's country strategy paper. What again is not elaborated in this document is the way in which these practices generate a gendered ideology that renders girls inferior to men leaving them vulnerable to violence and oppression. The 'symbolic' impact of these practices referred to in this passage clearly indicates the deep-rooted and often subconscious impact these practices have in shaping attitudes and behaviours towards women. DFID however fail to pick up on this choosing instead to focus on an imagined link between harmful cultural practices and HIV/AIDS.

The following is an example of a contract between the Norwegian Ministry of Foreign Affairs and Oxfam. Here we see the adoption of language which is more nuanced. The use of the term harmful cultural practices is not used but instead harmful sociocultural factors that risk causing HIV. 
One academic at the College of Medicine told me to go to NAC as 'they have commissioned most studies on sexual cultural practices including funding the work of NGOs' (P51). When interviewing a Research Officer at NAC (p. 46) he described four research reports to support his view and to provide evidence that cultural practices increase vulnerability to AIDS. What is interesting is to see who funds these studies. Those mentioned were a study conducted by the College of Medicine in Blantyre (2005) funded by the NAC. This study was conducted among three ethnic groups of Malawi (the Yao of Balaka, the Chewa of Mchinji and the Sena of Nsanje) and mapped cultural practices and assessed the influence of these on sexual and reproductive health (SRH) outcomes and HIV transmission. The data analysed in this report were collected using qualitative research methods. The evidence presented in this report was a result of 179 interviews conducted in the three sites. These included key informant interviews with traditional leaders, religious leaders, community elders, parents of new initiates, traditional healers, traditional birth attendants, traditional sex counsellors and religious sex counsellors. In-depth interviews were also conducted with married men and women, new traditional and faith-based initiates, recently married men and women, widows, widow inheritors, widowers, fisiis, individuals who refused to be cleansed, widows who refused to be inherited, inherited women and participants in ceremonial dances. Study sites were selected villages in Njolomole in Ntcheu, Makanjira in Mangochi and Ndamera in Nsanje. Selection of these sites was purposive and the research process was guided by advice from the District Commissioners and Traditional Authorities. This report did present biomedical evidence and presented the argument that HIV is difficult to contract. It also stated that:

It follows from the low transmission probabilities of HIV that the most dangerous cultural practices are heterosexual relationships in which sex is frequent, the partner is likely to be infected, and sex is likely to be unprotected. Conversely, the least dangerous are those in which sex is infrequent, the partner likely to be uninfected, and sex is likely to be protected. Other cultural practices such as traditional healing and circumcision are likely to be risky where the same and unsterilized instrument is used. (2005, p. 10)

The above paragraph is interesting because it shows how, despite the fact the report presents the epidemiological evidence, it was still deemed necessary to carry out an in-depth study on cultural practices and AIDS. 
A report by the Human Rights Commission of Malawi, funded by the Norwegian Agency for Development Cooperation (NORAD) through UNDP and UNICEF, entitled Cultural Practices and their Impact on the Enjoyment of Human Rights, Particularly the Rights of Women and Children in Malawi was also cited. This report made the link between HIV/AIDS and cultural practices by focusing on the human rights narrative and by holding the view that cultural practices are a violation of women's rights. He listed two further studies described as The Priorities in Local AIDS Control Efforts (PLACE) which is a rapid assessment method for identifying areas likely to have sexual partnership formation patterns capable of spreading and maintaining HIV infection. One was entitled 'An Assessment of Risk Practices and Sites where such Practices take place in the urban areas of Lilongwe and Blantyre Districts' (Kadzandira and Zisiyana 2006) and funded by the US Centres for Disease Control and Prevention. This study included a section referred to 'factors that could be facilitating HIV transmissions in the cities of Lilongwe and Blantyre as reported by other patrons'. The factors listed were ignorance/not valuing condom use; poverty/unemployment/more orphans; promiscuity/high sexual partnerships; lack of sensitisation; too much drinking/smoking joints; high cash flow and social life; high population/mobility; peer pressure and other factors.

A second PLACE study also funded by the Centres for Disease Control and Prevention was conducted in July 2006 'to identify sites, events or locations where risky behaviours take place i.e. where people meet new sexual partners and to assess the reach of HIV prevention interventions in these places' (2006, p. vii). This study took place in Nsanje and the passage below highlights that HCP have been placed into the category of risky sexual behaviour, yet again the medical evidence does not support this:

The prevalence of HIV/AIDS in Nsanje has remained very high (>30\% among sentinel surveillance women) and it is for this reason that NAC with funding from the Centres for Disease Control and Prevention (CDC) commissioned the PLACE study in the district so as to generate information that would help in designing prevention interventions. On sexual practices, sexual cleansing to protect widows/widowers, their families and village clans or their property is still being practiced and there are well structured groups who are hired to perform the function at a fee. (2006, p. 1) 
This passage also highlights how people focus on Nsanje as a region. This region has been identified as problematic because of the high HIV prevalence rates therefore a link is made between high observation of harmful cultural practices and assumed high transmission rates. This link is not borne out in the national level statistics on prevalence. During this interview I was also told that policy development begins from such studies mentioned above then a research dissemination meeting takes place followed by a planning meeting to take forward the policy recommendations outlined in the research reports. This statement by the NAC staff member demonstrates how perceptions of sexual cultural practices filter upwards and help shape international development policy. These examples demonstrate that these reports act as evidence convincing policymakers that they are right to pour money into HIV/AIDS programmes which focus on the eradication of HCPs because the donors cite these reports and evidence them.

In an interview conducted in Balaka with a district youth officer I was told that cultural practices are addressed in the gender policy and to implement the gender policy a project was designed called women-girls HIV/AIDS which was funded by the Global Fund (P14). It then transpired that the policy was developed in Lilongwe and that a UN taskforce came to Malawi and decided the project was important as a key way of bringing HIV/AIDS transmission rates down rather than as a way of improving the position of women. Although the district was implementing the project staff are not informed of the size of the budget but they were given a motorcycle and ten bicycles for peer educators 'who are communicating to the community on issues of gender and HIV/AIDS' (P14) by training peer educators and area development committees. This provides an example of the nature of training, for example the training focused around the need for communities to no longer observe those practices thought to increase HIV/AIDS. The reasoning was not based on the negative impact these practices have on the empowerment of girls but on their supposed link to HIV transmission.

In Malawi's national gender-based violence strategy (2002-2006) it states:

Special thanks are due to GTZ (Deutsche Gesellschaft fur Technische Zusammenarbeit) for funding a consultant and organising a workshop to solicit the views of stakeholders. Awareness and education programmes on GBV to eliminate harmful cultural practices will directly contribute to 
reducing risk for girls and women to become infected with HIV/AIDS. Key activities are mainstreaming gender-based violence issues alongside HIV/AIDS in staff training programmes and workplaces. $(2002$, p. 3 )

This shows how the German technical agency is funding work in Malawi to eliminate harmful cultural practices. I interviewed a Programme Officer working for UNAIDS who linked cultural practices and AIDS. She informed me that the Flemish government is providing funding for a study on cultural practices. She said that UNAIDS then gives the funds to the Government of Malawi to implement the AIDS programme and to work on cultural practices. The Programme Officer informed me that cultural practices 'are major things that are issues within the communities'. She said that 'the Flemish will be interested to know what is the status in terms of culture within the country' (P25). This example shows how an international donor is funding research on cultural practices and AIDS.

When I interviewed a staff member at USAID she told me that the final evaluation of a BRIDGE project was being conducted which addressed cultural practices. BRIDGE is an NGO working on BCI In Malawi which USAID funded and provided technical support. Aims of the evaluation were to assess progress in mitigating the impact of HIV/ AIDS in Malawi and identify lessons learned and make recommendations for USAID/Malawi to explore in designing future programmes (USAID 2008). The report refers to 'unhealthy cultural practices'. She said that in terms of initiation rites the Traditional Authority still continued with the ceremony but changed it in light of HIV/AIDS. Others also reported how the practice was changed in light of HIV/AIDS for example condoms are used or the act is only symbolic. This highlights the extent to which the primary concern was the risk that harmful cultural practices present to HIV/AIDS rather than the way in which these practices feed into and help maintain patriarchal values. The fact the practices remain even in symbolic form, and that the donor is not concerned to see them eradicated highlights the level of their ignorance in terms of how these practices exacerbate violence towards women. When interviewing the country director, GTZ, I asked if she thought cultural practices contribute to the spread of HIV, she explained:

Yes of course but you don't see them if you live in Lilongwe or Blantyre. Before I came here as country director I used to come to Malawi and 
visited very, very remote areas to monitor and evaluate programmes. It's a completely different world. Witchcraft takes place and traditional culturally-bound things. (P37)

This comment shows that she thinks cultural practices only take place in remote areas thus reinforcing the views of the Malawian elite I presented in Chapter 4 who try and distance themselves from the high transmission rates by blaming 'the backward culture' of rural communities. However, this is not the case as witchcraft and other forms of African Traditional including traditional healing and medicine also take place in urban areas (Englund 2002). This interview highlights the way that this perception of a backward rural 'other' has influenced and shaped the views of at least some members of the international donor community. She goes on to talk about cultural practices:

Cultural practices can be disasters for example if you can't get pregnant. Not in Lilongwe or Blantyre but if you cannot get pregnant you would go to a traditional healer. Some of the traditional leaders would contribute to the spread of the disease and would bring in someone to have sex with the woman. (P37)

As pointed out in Chapter 3 where I presented the epidemiology of AIDS this is medically inaccurate. These are examples of how international donors are funding work on cultural practices. Again we see how donors are funding projects to reduce harmful cultural practices because of the primary link to HIV/AIDS not because they represent forms of gender-based violence. So how do these distorted perceptions become so dominant in the international donor community?

\section{Donors Must Get Out More}

Donors cover a huge range of organisations; some spend huge amounts of time in the field (e.g., INGOs with country offices), others never visit (e.g., Big Lottery Fund), while others are in between (e.g., DFID staff). However based on my findings a fundamental aspect is the lack of evidence and the fact that donors that are based in the capital of Malawi do not get out into the field often enough means they have a lack of insight into local conditions. Therefore certain donors will accept the 
views of what goes on in rural communities provided by the Malawian elite whose own agenda was outlined in Chapter 4. For example when I interviewed the HIV/AIDS cluster leader for USAID he said he would like to go out and visit projects more. A DFID officer told me he could not answer any of my questions about sexual cultural practices and had no knowledge about them and said he 'rarely went to the field'. He told me to talk to his Malawian counterpart as he said 'she knows more than me [about cultural practices]'. He also told me he could not talk about cultural practices but could talk about policy. He then went on to say that 'we ensure that we are aware of impact. We think the HIV/AIDS programme is pretty good. Some of it is remarkable' (P4). He also stated that he agreed with the links made between HIV/AIDS and HCP, so despite his willingness to acknowledge he does not go into the field and has no direct understanding - the view on prevalence he puts forward is essentially the narrative of blame constructed by the Malawian elite.

During my consultancy with UNAIDS I asked the question 'How many AIDS-related missions were undertaken by your agency in the last 12 months (either from your headquarters or instigated from the country office)?' The following are some responses (Box 6.2).

\section{Box 6.2 Response to UNAIDS question}

"Five in the last six months. So ten. It is our plan to improve this. We are weak on these kinds of missions. We attend conferences and workshops but not real, real missions."

UNAIDS Office, 16/04/09

"Six."

United States Group [USG] Country Coordinator for US Government AIDS Programme PEPFAR 29/04/2009

"We keep a log for incoming missions and they come and support those areas that we itemised. Missions are not instigated by HQ or head office."

Request from Ministry. WHO 29/03/2009

"We have district based staff so we make visits twice every month." 
Thomas Kisimbi, Country Director, Clinton Foundation $17 / 04 / 2009$

"Finances, one per month one per quarter."

Director MBCA

"We have contributed a lot and received recognition from NAC to see the work we are doing. We have visited thousands of organisations are visited. Irish Aid also funds some of our work. Not specifically speak about HIV/AIDS but different components Irish Aid mission. Great interest in our work. Help to guide us in terms of what are the best practices out there. Cross cutting issues about gender rights tremendous added value to our work. So I would not be able to quantify the exact number of times".

Concern Universal 20/04/2009

"Yes the National AIDS Commission comes once a year but then they came three times to look at the construction work taking place for the new lecture theatres".

College of Medicine 22/04/2009

"Five in country mission in March from HQ but in the last twelve months we have had two in country missions."

EU office, 16/04/2009

"Two Irish Aid delegates and the Irish Ambassador have visited the programmes in Nsanje district."

GOAL MALAWI

"No visits."

Former HIV and AIDS Coordinator,

GTZ, $12 / 05 / 2009$

"So many times. NAC, DFID, Scottish Executive and BRIDGE".

MANASO 20/04/2009

"2 times" Mwanza district 30/04/2009

"6 times" Toveraine 30/04/2009 


\section{How Narratives Have Been Passed on Through Education}

The narratives of blame also feed into the education system via the curriculum. Curriculum-based education books are used by teachers in schools in Malawi to teach students about developing life skills. UNFPA, NORAD and Swedish International Development Agency (SIDA) funded the development of these text books. I analysed a complete set $(2002,2004,2008)$. In 2002 cultural practices were referred to and described as both helpful and harmful. This book referred less to HIV/AIDS. In 2004-2008 however more references were made to harmful practices and HIV/AIDS. Pertinent issues featured in these books were cultural practices and HIV/AIDS, gender and HIV/AIDS and human rights and HIV/AIDS.

In the senior secondary life skills education student's book (Fabiano 2002) cultural practices are reported to encourage the spread of HIV/ AIDS. An activity section on 'harmful cultural practices' asks students to:

- Brainstorm cultural practices,

- Work in groups to identify cultural practices which are harmful and those which are not harmful,

- Report your findings to class for discussion,

- Discuss in groups practical solutions to each of the harmful cultural practices, and

- Report your findings to class for discussion.

Cultural practices referred to as harmful include fisi (hyena), male circumcision, female circumcision, tattooing for beautification or administration of charms, widow inheritance (chokolo) and death cleansing (kuchotsa kufa). The fisi is described as a man from the village who is given the role of sleeping with young girls as part of their initiation into womanhood (Mthanga et al. 2002). What is unclear is why these practices were identified as harmful as there is no explanation as to why they are deemed harmful. Through the curriculum this narrative of blame is being introduced to children shaping the way they see this issue. The textbooks are funded by international donors who see this approach as an important way of challenging HIV/AIDS as it directly focuses on changing behaviour and attitudes (Box 6.3). 


\section{Box 6.3 Questions for students on cultural practice and HIV/AIDS}

Review questions

1. Give three examples of cultural practices that facilitate the spread of HIV/AIDS.

2. Give three examples of cultural practices that help in the prevention of HIV transmission

3. Explain how each of the examples you have given in (1) facilitates the spread of HIV/AIDS.

4. Write an essay on the impact of HIV/AIDS in your community

5. Suggest ways of alleviating the impact of HIV/AIDS on the community.

\section{P109}

Review questions

1(a) Give three examples of negative effects of foreign culture and technology on indigenous cultural and traditional practices

(b) Explain the importance of critical thinking before adopting foreign culture and technology.

2. Explain the importance of critical thinking before adopting foreign culture and technology.

3. Write an essay on the impact of HIV/AIDS on the nation and the world.

4. Suggest ways of alleviating the impact of HIV/AIDS on the nation and the world.

The exercises in curriculum-based books mentioned above demonstrate how misconceptions concerning sexual cultural practices and HIV/AIDS are embedded in people's views at an early age. Research shows that well-designed and well-implemented HIV prevention programmes can significantly reduce sexual risk behaviours among young people and schools should be key to supporting effective HIV prevention among youth. However teaching young people about harmful cultural practices will not lead to a reduction in risky sexual behaviour. As I have outlined the damaging impact of HCP is far more nuanced than immediately rendering girls vulnerable to HIV transmission.

In an interview with a civil servant at the Health Education Unit, Lilongwe (P45) I met him at his office in October 2008. He told me that 
the Salvation Army did work to develop materials on cultural practices and AIDS. He said the fisi practice and kusasa fumbi exist. He said in the course of learning adult language, adult techniques they get a woman for a boy and a man for girls. He said they are scared that if they don't do it they will experience drying of skin-coarse skin. He said children practice sex but if they have sex with someone who is infected they get infected. He said that the Health Education Unit is producing a manual and is waiting for funds from headquarters to translate into Chichewa and Chitumbuka. The manual describes how to get into communities and address cultural practices and how to approach traditional leaders and convince them to change the practices. The manual includes sections on: types of relationships; relationship with HIV; Approach; What is it? Cultural practices; What can they do? And what are the dangers? He said the manual will be used by 'change agents' in other words, anyone involved in the issues. $\mathrm{He}$ said evidence is difficult to come by and what is needed is a control-a community that hasn't made changes and a community that has. He said evidence for this manual was obtained from interviewing Initiated girls and initiated boys in Mulanje. The Health Education Unit used the information from this research to develop materials.

A PowerPoint presentation I was given by the Seventh-day Adventist Church concerning a Clinic \& Community Service Initiative of Adventist health services which spoke about an integrated clinic and community HIV/AIDS/STI prevention project was funded by USAID through the Umoyo network. The programme's objectives included creating awareness on the dangers of harmful cultural practices and advocating for the modification of harmful cultural practices. The presentation also listed positive and negative cultural practices as follows (Box 6.4).

\section{Box 6.4 PowerPoint presentation by the Seventh-day Adventist Church}

- Positive

1. Lobola

2. Kumeta

3. Chinamwali

4. Chikamwini/ Chitengwa

5. Wife inheritance to a certain extent
- Negative

1. Fisi

2. Polygamy

3. Magolowazi

4. Property grabbing

5. Post menopausal cessation of intercourse

6. Use of herbs to dry out and tighten of vagina 
The presentation then outlines the roles played by the Adventist health services and the community (Box 6.5).

\section{Box 6.5 PowerPoint presentation by the Seventh-day Adventist Church Cont}

- Adventist Health Services

1. Facilitate focus group discussion on cultural practices that promote the spread of HIV virus.

2. Train Community based HIV counsellors.

3. Introduce VCT services in two of the nine Supervision areas.
- Community

1. Review cultural practices in relation with HIV/AIDS.

2. Modify cultural practices that promotes the spread of HIV virus.

\section{Where Is the Evidence?}

This section presents data from the consultancy I conducted with UNAIDS. The question asked to stakeholders involved in HIV/AIDS was Does your organisation use evidence to inform policy and programmatic decisions on HIV/AIDS? (Box 6.6).

This section demonstrates that evidence to inform policies and programmes on HIV/AIDS is weak.

\section{Box 6.6 Data from UNAIDS consultancy}

Yes $\quad$ Please provide examples

No Do you have plans to improve on this in the future? Please give examples

Director of Planning, Ministry of Health 20/04/2009

This is one area that is still a challenge. We are supposed to do this. Monitoring and Evaluation (M\&E) is one area where we need to do a little bit more work. In the districts at the health level, for example in rural health centres we have M\&E officers. We don't have specialised information so we are grappling with non- trained statisticians. 
They know the policy requires a certain quality of information and timeliness of providing that information and also ownership of that information. Like HIV/AIDS, TC has vertical silos that have their people. The programme wants to correct Malawi Integrated Health Survey (MIHS) one guy needs to sit down and address it is an issue for example MIHS timeliness and quality of reporting for evidence based planning. We are using programme information to request the government department to create positions for $\mathrm{m}$ and e graduates. This has not yet happened but the request has been made.

Director, MBCA 22/04/1999

Yes it is based on evidence - what is working well with some of our partners. During $\mathrm{m}$ and e visits and biannual review meetings. New members study visits looking at best practices.

Alliance One 20/04/2009

Increase in number of employees with STI's necessitated the company to scale up condom use awareness for those that cannot abstain or stick to one partner. Our clinic registered for ART programme having looked at statistics of employees whose health status was deteriorating as a result of being HIV positive. Referring employees for ART to other health facilities e.g The Light House was proving problematic due to the large number of people looking for the same service.

Concern Universal implementing partner 20/04/2009

We do work internally for advocacy at the national level but we have not played an advocacy role to influence policy at the national level. We are trying to influence the extended NAF in terms of what should be some of the priorities we should be focusing on. Within the room 3 organisations from a perspective. Such things are areas that we have tried to influence.

Doctor, College of Medicine 22/04/2009

I suppose we have to say. What constitutes evidence? There is awareness in university of Malawi. HIV is having an impact both in and outside, members of staff. I cannot remember exactly what the source was how many members of staff died as a result of HIV/AIDS. We need to have an HIV/AIDS policy. Distant memory no formal report 
or assessment done to inform policy most policies are made with elements of general knowledge. What other institutions may have. Research in my view the gold standard of evidence is the randomised control trial. Observational studies, audits. Type of evidence I have articulated we see what is happening in other parts of the world. Great knowledge.

ESCOM 20/04/09 This one yah what happens is through these M\&Es through these surveys. Our HIV/AIDS policy developed in 2001; reviewed in 2006. Provisions of nutritional supplements Living with HIV/AIDS. Incorporate into programme. Employees. As of now providing ARVs into clinic. After revision. Use evidence. After collecting data go through the responses from questionnaires - steering committee - we haven't reached out through the north. Let's do this, coming up with the results. Do presentation with executive mgt outcome of the survey communicate to my employees. Newsletter produced to all employees. Human resources. Member of staff can access.

Questions about HIV/AIDS. The rest don't know.

GOAL HIV/AIDS M\&E Manager 27/04/2009

GOAL Malawi conducts KAPB surveys to determine what issues are there on the ground that need to be addressed. For example, in the past year, GOAL Malawi discovered that stigma and discrimination still exists in the communities and then developed specific interventions to reduce stigma and discrimination and also carry out advocacy campaigns.

MANASO 24/04/2009

Yes a number of activities are actually informed by what is coming from our constituencies. Information from them helps us come up with new programmes. Technical support that we provide to the members workshop set up only thirty members. When we saw that people were under-utilising that. We had to ask them why they weren't implementing what they had learnt. 1. Had not understood. 1. Language barrier. Changed our strategy on site technical support all group members would be present. Ten to fifteen members remind each other. Needs driven. Workshops when the needs are similar. Do have national workshops. 


\section{MANET+ PROG OFFICER 24/04/2009}

Yes. We have done that. Research on stigma and discrimination that has informed the policy. Part of the policy development process. Also one of the challenges we are facing. Donors not much willing to support, research and $\mathrm{m}$ and e just looking at implementation. Stigma response. No nationwide study. Evidence base. For us you will see the irony not only reporting to NAC. In terms of the donors that require support. Results. To follow up on how we can deal with the challenges that we face. Not equated with resources. Development partners not ready to support us on results.

Of course HIVOS supporting in terms of $\mathrm{m}$ and e. not expect results on the ground. Want the evidence. Want to hear voices. Results on the ground hear a story. Home based care. Dutch humanist comic relief interested in results. Can share USAID. Not just interested in outputs, success stories. What change have you brought. Voices must be reflected. This is what is not in comparison. There is a lot of money come through NAC programmes. Most of work is advocacy. Difficult to measure. Many partners influencing us. Difficult. Combined interventions. Difficult for one organisation to take success. Good to look at the result. That requires resource. Proportion of monitoring. For NAC come up with a three year proposal. Make much sense. Previous implementation. That is the situation on the ground. Come up with another three year strategy. More or less ready just to get what we are presenting. To some extent not ready to face what we are doing. Why is that we are not making significance strides in behaviour change. That awareness not translated into behaviour change. Over what period. Really moved down. Looked at same methodology. Maybe have shifted the goalposts.

Ministry of Education, 28/04/2009

Yes the evidence analysing the capacity of teachers living +. Issues to be discussed there. Report is here. Take to management to react towards problems identified.

Ministry of Local Government, "no” 29/04/2009 
Mzimba district council 29/04/2009

Yes district HIV/AIDS has affected us all. Something that when we are implementing has to be mainstreamed. For example if we look at BCI in the district most of them like going to South Africa leaving spouses behind. Wife stays does other things. Created situation need to sensitise the communities to let them know it is more serious. Presenting them to the behaviours. Base all activities if we find if that is a problem. HTC week. If people go for htc if they found positive this area going towards levels we need to act urgently.

Mzudza 20/04/2009

Yes we do that. Chairman at the ministry level.

Toveraine 29/04/2009

For our programme we go to the field and assess. Quality Assessment sponsored by Umoyo network. Activities based on what we did during that survey.

Any evidence to inform policy decisions? Trocaire conducted an HIV/AIDS scoping study and a gender study. HIV highly subscribed. Trocaire does not have skills or capacity to fill important gap (P27 09/03/2010).

\section{CONCLUSION}

This chapter examines the complexities of the donor funding process, how inaccuracies come into play, and how reality has become distorted; I have evidenced that distortion and looked at how different narratives merge which then hinder the effectiveness of prevention programmes. Policies and programmes are affected as they are not supported by epidemiological evidence. This is why it has been important to talk about the policy process. If the policy process had been dealt with in a different way and evidence was used to support the policy decision then perhaps HIV prevention programmes would be more effective. 


\section{REFERENCES}

Ainsworth, M., \& Teokul, W. (2000). Breaking the silence: Setting realistic priorities for AIDS control in less-developed countries. The Lancet, 356(9223), 55-60.

Anderson, J. E. (1984). Public policymaking: An introduction (3rd ed.). Boston, MA: Houghton Mifflin.

Bakewell, O., \& Garbutt, A. (2005). The use and abuse of the logical framework approach. Stockholm: Swedish International Development Cooperation Agency (Sida).

Bebbington, A. (2005). Donor-NGO relations and representations of livelihood in non-governmental aid chains. World Development, 33(6), 937-950.

Bourdieu, P. (1988). Vive la crise! For heterodoxy in social science. Theory and Society, 17(5), 773-787.

Brock, K., \& McGee, R. (Eds.). (2002). Knowing poverty: Critical reflections on participatory research and policy. London: Earthscan.

Brock, K., Cornwall, A., \& Gaventa, J. (2001). Power, knowledge and political spaces in the framing of poverty policy. Sussex, UK: Institute of Development Studies.

Buse, K., Mays, N., \& Walt, G. (2005). Making health policy. London: Open University Press.

Case, K. K., Ghys, P. D., Gouws, E., Eaton, J. W., Borquez, A., Stover, J., et al. (2012). Understanding the modes of transmission model of new HIV infection and its use in prevention planning. Bulletin of the World Health Organisation, 90(11), 831-838A.

Castells, M. (1996). The rise of the network society. Oxford, UK: Blackwell.

Chin, J. (2007). The AIDS pandemic: The collision of epidemiology with political correctness. Oxford: Radcliffe Publishing.

Clay, E., \& Shaffer, B. (Eds.). (1994). Room for manoeuvre: An exploration of public policy in agriculture and rural development. London: Heinemann.

College of Medicine. (2005). Cultural practices related to sexual and reproductive health outcomes and HIV transmission. Blantyre: College of Medicine.

Coombes, Y. (2001). A literature review to support the situational analysis for the national behaviour change interventions strategy on HIV/AIDS and sexual and reproductive health. London: DFID.

Cornwall, A. (2002). Making spaces, changing places: Situating participation in development. Sussex, UK: Institute of Development Studies.

Crewe, E., \& Young, M. J. (2002). Bridging research and policy: Context, evidence and links. London: Overseas Development Institute.

Dionne, K. Y. (2011). Local demand for a global intervention: Policy priorities in the time of AIDS. World Development, 40(12), 2468-2477.

Dorman, S. (2005). Studying democratization in Africa: A case study of human rights NGOs in Zimbabwe. In T. Kelsall \& J. Igoe (Eds.), Between a rock and a hard place: African NGOs, donors and the state (pp. 33-59). Durham, NC: Carolina Academic Press. 
Englund, H. (2002). The dead hand of human rights: Contrasting Christianities in post-transition Malawi. The Journal of Modern African Studies, 38(4), 579-603.

Fabiano, E. (2002). Senior secondary science and technology: Students book 3. Blantyre, Malawi: Macmillan Malawi.

Feeny, S., \& McGillivray, M. (2004). Modelling inter-temporal aid allocation: A new application with an emphasis on Papua New Guinea. Oxford Development Studies, 32(1), 101-118.

Foley, E. E., \& Nguer, R. (2010). Courting success in HIV/AIDS prevention: The challenges of addressing a concentrated epidemic in Senegal. African Journal of AIDS Research, 9(4), 325.

Foltz, A. M. (1996). The policy process. Geneva: World Health Organization (WHO).

Foucault, M. (1979). The history of sexuality, vol. I: An introduction. New York: Random House.

Foucault, M. (1991). Discipline and punish: The birth of the prison. London: Penguin.

Fourie, P. (2006). The political management of HIV/AIDS in South Africa: One burden too many?. Basingstoke, UK: Palgrave Macmillan.

Gasper, D., \& Apthorpe, R. (1996). Discourse analysis and policy discourse. The European Journal of Development Research, 8, 1-15.

Gaventa, J. (2006). Finding the spaces for change: A power analysis. IDS Bulletin, 37(6), 23-33.

Grindle, M., \& Thomas, J. (1991). Public choices and policy change: The political economy of reform in developing countries. Baltimore: John Hopkins University Press.

Haas, P. M. (1992). Epistemic communities and international policy coordination: Introduction. International Organisation, 46(1), 1-35.

Hajer, M. A. (1995). The politics of environmental discourse. Oxford: Oxford University Press.

Hajer, M., Hajer, M. A., \& Wagenaar, H. (Eds.). (2003). Deliberative policy analysis: Understanding governance in the network society. Cambridge University Press.

Heclo, H. (1972). Policy analysis. British Journal of Political Science, 2(1), 83-108.

Hogwood, B. W., \& Gunn, L. A. (1984). Policy analysis for the real world. Oxford: Oxford University Press.

Institute of Development Studies. (2006). Understanding policy processes: A review of IDS research on the environment. Sussex, UK: IDS.

Jones, E., \& Gaventa, J. (2002). Concepts of citizenship: A review. Sussex, UK: IDS. Jones, N., Datta, A., \& Jones, H. (2009). Knowledge, policy and power: Six dimensions of the knowledge-development policy interface. London: Overseas Development Institute (ODI). 
Kadzandira, J. M., \& Zisiyana, C. (2006). Assessment of risk practices and sites where such practices take place in the urban areas of Lilongwe and Blantyre districts. Zomba: Centre for Social Research.

Kaler, A., \& Watkins, S. (2001). Disobedient distributors: Street-level bureaucrats and would-be patrons in community based family planning programs in rural Kenya. Studies in Family Planning, 32(3), 254-269.

Keeley, J., \& Scoones, I. (1999). Understanding environmental policy processes: A review (Vol. 89) (IDS Working Paper).

Keeley, J., \& Scoones, I. (2000). Environmental policymaking in Zimbabwe: Discourses, science and politics. Sussex, UK: IDS.

Keeley, J., \& Scoones, I. (2003). Understanding environmental policy processes: Cases from Africa. London: Earthscan.

Lasswell, H. D. (1956). The decision process. College Park, MD: University of Maryland Press.

Latour, B. (1996). Aramis, or the love of technology (C. Porter, Trans.). Cambridge, MA and London: Harvard University Press.

Lewis, D., \& Kanji, N. (2009). Non Governmental Organizations and Development. Oxon: Routledge.

Lindblom, C. E. (1980). The policy-making process. Englewood Cliffs, NJ: Prentice Hall.

Lipsky, M. (1980). Street-level bureancracy: Dilemmas of the individual in public service. New York: Russell Sage.

Luke, N., \& Watkins, S. C. (2002). Reactions of developing-country elites to international population policy. Population and Development Review, 28(4), 707-733.

Macrae, J. (2001). Aiding recovery: The crisis of aid in chronic political emergencies. London: Zed Books.

Marsland, R. (2006). Community participation the Tanzanian way: Conceptual contiguity or power struggle? Oxford Development Studies, 34(1), 65-79.

Matinga, P., \& McConville, F. (2003). A review of cultural beliefs and practices influencing sexual and reproductive health and health-seeking behaviour, in Malawi. Lilongwe: Department for International Development Malawi (DFID).

McGee, R. (2004). Unpacking policy: Actors, knowledge and spaces. In K. Brock, R. McGee, \& J. Gaventa (Eds.), Unpacking policy: Actors, knowledge and spaces in poverty reduction (pp. 1-26). Kampala: Fountain Press.

Moran, D. (2004). HIV/AIDS, governance and development: The public administration factor. Public Administration and Development: The International Journal of Management Research and Practice, 24(1), 7-18.

Mosse, D. (2004). Is good policy unimplementable? Reflections on the ethnography of aid policy and practice. Development and Change, 35(4), 639-671.

Mthanga, A. S., Maluwa-Banda, D., Chiziwa, S. E., \& Mphande, D. K. (2002). Senior secondary life skills education, student's book 3 and 4. Blantyre: Macmillan. 
Potts, M., Halperin, D. T., Kirby, D., Swidler, A., Marseille, E., Klausner, J. D., et al. (2008). Reassessing HIV prevention. Science, 320(5877), 749-750.

Putzel, J. (2003). Institutionalising an emergency response: HIV/AIDS and governance in Uganda and Segal. London: London School of Economics and Political Science (LSE), Crisisstate Research Centre (CSRC).

Putzel, J. (2004). The global fight against AIDS: How adequate are the National Commissions. Journal of International Development, 16(8), 1129-1140.

Putzel, J., Denis, P., \& Becker, C. (2006). A history of state action: The politics of AIDS in Uganda and Senegal. The HIV/AIDS epidemic in sub-Saharan Africa in a historical perspective, pp. 171-184.

Ramalingam, B., Jones, H., Reba, T., \& Young, J. (2008). Exploring the science of complexity: Ideas and implications for development and humanitarian efforts. London: ODI.

Roe, E. (2005). Development narratives, or making the best of blueprint development. In M. Edelman \& A. Haugerud (Eds.), The anthropology of development and globalization: From classical political economy to contemporary neoliberalism (pp. 313-322). Oxford, UK and Malden, MA: Blackwell.

Roe, E. (1991). Development narratives, or making the best of blueprint development. World Development, 19(4), 287-300.

Sabatier, P. A. (2007). The need for better theories. In P. Sabatier (Ed.), Theories of the policy process. Boulder, CO: Westview Press.

Shiffman, J. (2008). Has donor prioritization of HIV/AIDS displaced aid for other health issues? Health Policy and Planning, 23(2), 95-100.

Shore, S., \& Wright, S. (Eds.). (1997). Anthropology of policy: Critical perspectives on governance and power. London and New York: Routledge.

Shelton, J. D., Halperin, D. T., \& Wilson, D. (2006). Has global HIV incidence peaked? The Lancet, 367(9517), 1120-1122.

Simon, H. A. (1957). A behavioral model of rational choice. In H. A. Simon (Ed.), Models of man, social and rational: Mathematical essays on rational human behavior in a social setting. New York: Wiley.

UNAIDS. (2004). Report on the global AIDS epidemic: Executive summary. Geneva, Switzerland: UNAIDS.

UNAIDS. (2008). 2008 report on the global AIDS epidemic. Geneva, Switzerland: UNAIDS.

UNAIDS. (2010). UNAIDS report on the global AIDS epidemic. Geneva, Switzerland: UNAIDS.

Wachira, C., \& Ruger, J. P. (2011). National poverty reduction strategies and HIV/AIDS governance in Malawi: A preliminary study of shared health governance. Social Science and Medicine, 72(12), 1956-1964.

Walt, G., \& Gilson, L. (1994). Reforming the health sector in developing countries: The central role of policy analysis. Health Policy and Planning, 9(4), 353-370. 
Webb, D. (2004). Legitimate actors? The future role for NGOS against HIV/ AIDS in sub-Saharan Africa. In N. K. Poku \& A. Whiteside (Eds.), The political economy of AIDs in Africa (pp.19-32). Hampshire, UK: Ashgate Publishing.

Whimster, S. (2007). Understanding Weber. New York: Routledge.

Young, E., \& Quinn, L. (2002). Writing effective public policy papers: A guide to policy advisors in Central and Eastern Europe. Budapest: LGI.

Young, J., \& Mendizabal, E. (2009). Helping researchers become policy entrepreneurs: How to develop engagement strategies for evidence-based policymaking. Briefing Paper, 53.

Open Access This chapter is licensed under the terms of the Creative Commons Attribution 4.0 International License (http://creativecommons.org/licenses/ by $/ 4.0 /$ ), which permits use, sharing, adaptation, distribution and reproduction in any medium or format, as long as you give appropriate credit to the original author(s) and the source, provide a link to the Creative Commons licence and indicate if changes were made.

The images or other third party material in this chapter are included in the chapter's Creative Commons licence, unless indicated otherwise in a credit line to the material. If material is not included in the chapter's Creative Commons licence and your intended use is not permitted by statutory regulation or exceeds the permitted use, you will need to obtain permission directly from the copyright holder.

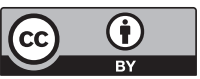

